\title{
Chemical Methods for Hydrolyzing Dairy Manure Fiber: A Concise Review
}

\author{
Noori M. Cata Saady ${ }^{1, * \mathbb{D}}$, Fatemeh Rezaeitavabe ${ }^{1}$ and Juan Enrique Ruiz Espinoza ${ }^{2}$ \\ 1 Civil Engineering Department, Memorial University of Newfoundland, St. John's, NL A1B 3X5, Canada; \\ f.rezaeitavabe@mum.ca \\ 2 Faculty of Chemical Engineering, Autonomous University of Yucatan, Periférico Norte, Km. 33.5, Tablaje \\ Catastral 13615, Col. Chuburná de Hidalgo Inn, Merida C.P. 97203, Mexico; juan.ruiz@correo.uady.mx \\ * Correspondence: nsaady@mun.ca
}

Citation: Saady, N.M.C.;

Rezaeitavabe, F.; Ruiz Espinoza, J.E. Chemical Methods for Hydrolyzing Dairy Manure Fiber: A Concise Review. Energies 2021, 14, 6159. https://doi.org/10.3390/en14196159

Academic Editors: Alberto $\mathrm{Coz}$ and Gabriele Di Giacomo

Received: 9 August 2021

Accepted: 24 September 2021

Published: 27 September 2021

Publisher's Note: MDPI stays neutral with regard to jurisdictional claims in published maps and institutional affiliations.

Copyright: (c) 2021 by the authors. Licensee MDPI, Basel, Switzerland. This article is an open access article distributed under the terms and conditions of the Creative Commons Attribution (CC BY) license (https:// creativecommons.org/licenses/by/ $4.0 /)$.

\begin{abstract}
This paper reviews the chemical hydrolysis processes of dairy manure fiber to make its sugar accessible to microorganisms during anaerobic digestion and identifies obstacles and opportunities. Researchers, so far, investigated acid, alkali, sulfite, and advanced oxidation processes (such as hydrogen peroxide assisted by microwave/ultrasound irradiation, conventional boiling, and wet oxidation), or their combinations. Generally, dilute acid (3-10\%) is less effective than concentrated acid (12.5-75\%), which decrystallizes the cellulose. Excessive alkaline may produce difficult-to-degrade oxycellulose. Therefore, multi-step acid hydrolysis (without alkaline) is preferred. Such processes yielded $84 \%$ and $80 \%$ manure-to-glucose and -xylose conversion, respectively. Acid pretreatment increases lignin concentration in the treated manure and hinders subsequent enzymatic processes but is compatible with fungal cellulolytic enzymes which favor low $\mathrm{pH}$. Manure high alkalinity affects dilute acid pretreatment and lowers glucose yield. Accordingly, the ratio of manure to the chemical agent and its initial concentration, reaction temperature and duration, and manure fineness need optimization because they affect the hydrolysis rate. Optimizing these factors or combining processes should balance removing hemicellulose and/or lignin and increasing cellulose concentrations while not hindering any subsequent process. The reviewed methods are neither economical nor integratable with the on-farm anaerobic digestion. Economic analysis and energy balance should be monolithic components of the research. More research is required to assess the effects of nitrogen content on these processes, optimize it, and determine if another pretreatment is necessary.
\end{abstract}

Keywords: dairy manure; fiber; lignocellulose; chemical hydrolysis; acid and alkaline hydrolysis

\section{Introduction}

Cattle manure is low-cost renewable lignocellulosic waste biomass that does not compete with food when used as a substrate for biofuel; therefore, it is currently under extensive research as feedstock for biofuel production. Table 1 gives manure production in several countries and indicates its potential as feedstock to biofuel production processes. In 2001, cattle produced around 86\% of the Canadian livestock manure, i.e., 146 million tonnes (wet basis) [1]. In the USA, 75\% of the livestock manure is from dairy and feedlot cattle [2]. Hence, US manure could generate about $7 \times 10^{11} \mathrm{MJ}$ annually through anaerobic digestion (AD), assuming an energy content of $13.4 \mathrm{MJ} \mathrm{kg}^{-1}$ manure [3]. Conversion of all Indian cattle manure produced in 2010 into biogas would have generated 17,850 million $\mathrm{m}^{3}$ of biogas [4]. Manure production is growing due to the growth of the livestock industry; for example, from 1981 to 2001, the Canadian total livestock manure production increased by $13.9 \%$ (21.7 million tonnes). Similarly, the US livestock manure production increased by 89 million tonnes (dry basis) between 2001 and 2008, while in India, it increased by $10.8 \%$ (71 million tonnes) from 1996 to 2010 (Table 1). Therefore, manure-to-energy is a competitive, sustainable, and environmentally friendly option to produce energy and 
be integrated into the bio-based economy. Unfortunately, livestock manure is still an undervalued and unexploited source of clean and renewable energy.

Table 1. Manure production in different countries.

\begin{tabular}{ccccc}
\hline Country & Year & $\begin{array}{c}\text { Wet Mass } \\
\left(\mathbf{1 0}^{\mathbf{6}} \text { Tonnes }\right)\end{array}$ & $\begin{array}{c}\text { Dry Mass } \\
\left(\mathbf{1 0}^{\mathbf{6}} \text { Tonnes }\right)\end{array}$ & Reference \\
\hline USA & 2016 & 2490 & $\mathrm{NR}$ & {$[5]$} \\
& 2008 & $\mathrm{NR}$ & 249 & {$[6]$} \\
Canada & 2001 & $\mathrm{NR}$ & 160 & {$[7]$} \\
Europe Union & 2001 & 178 & 35 & {$[1]$} \\
& 2014 & 1380 & $\mathrm{NR}$ & {$[8]$} \\
China & 1993 & 1100 & $\mathrm{NR}$ & {$[10]$} \\
& 2014 & $\mathrm{NR}$ & 551 & {$[11]$} \\
India & 2008 & 7300 & $\mathrm{NR}$ & {$[12]$} \\
& 2010 & 659 & $\mathrm{NR}$ & {$[13]$} \\
Iran & 1996 & 69 & $\mathrm{NR}$ & {$[14]$} \\
Egypt & 2015 & 50 & $\mathrm{NR}$ & {$[15]$} \\
Greece & 2011 & 17 & $\mathrm{NR}$ & {$[16]$} \\
Brazil & 2010 & 2302 & $\mathrm{NR}$ & \\
\hline
\end{tabular}

Note: $\mathrm{NR}=$ not reported.

Animal manure anaerobic digestion (AD) can be integrated into a comprehensive farm management system and generates income. At the same time, it produces biogas, eliminates pathogens [17], controls odor, reduces water pollution, recovers nutrients, produces fertilizers, and ultimately improves environmental quality. Cattle manure comprises cow feces, urine, and bedding material such as straw and wood shavings. Around $45-50 \%$ of the manure's dry matter (DM) is lignocellulose (hemicellulose, cellulose, and lignin). Lignocellulose contains reduced carbon (rich in electrons). Although cow manure has relatively high cellulosic content (20-26\% of the dry matter (DM)) not all its volatile solids (VS) can be converted to methane $\left(\mathrm{CH}_{4}\right)$ because cellulose and hemicellulose are protected by lignin which is non-biodegradable in anaerobic digestion. Generally, manure bioconversion into methane proceeds slowly (around 30 days). In addition, dairy manure's biodegradable VS is about $40 \%$ [18] because they are lignocellulose. Typically, only $60 \%$ of the cellulose content of manure is converted to methane, while the rest leaves the digester because it is inaccessible to the microorganisms since it is protected by lignin. Therefore, the methane yield is also low compared to other feedstocks [19].

To date, little has been done to recover the ultimate potential energy in cattle manure through bioprocesses. This is mainly because of the complex physicochemical composition of manure (Chen et al., 2003); thus, preliminary studies to convert all reduced-carbon in manure to biofuel on a large-scale basis have not been successful $[7,20]$. New simple and low-cost innovative pre-processes are required to depolymerize the lignocellulosic fiber of manure and make all its reduced carbon accessible to fermentative bacteria during AD. The lignocellulosic fraction of manure has to be hydrolyzed into simple sugar monomers such as glucose and xylose. Microbes in AD can ferment and convert these sugars to methane. Therefore, pre-processes must economically hydrolyze animal manure and be integrated with the on-farm AD to increase farmers' income while treating waste [7]. Overall, several physical, chemical, and biological hydrolysis methods and some of their combinations have been investigated in one- and two-stage processes to increase the sugar yield from dairy manure. Figure 1 shows a schematic of the potential integration of these hydrolysis methods in dairy manure anaerobic digestion. This paper reviews previous research on chemical methods investigated to hydrolyze dairy manure fiber and identifies obstacles and opportunities. 


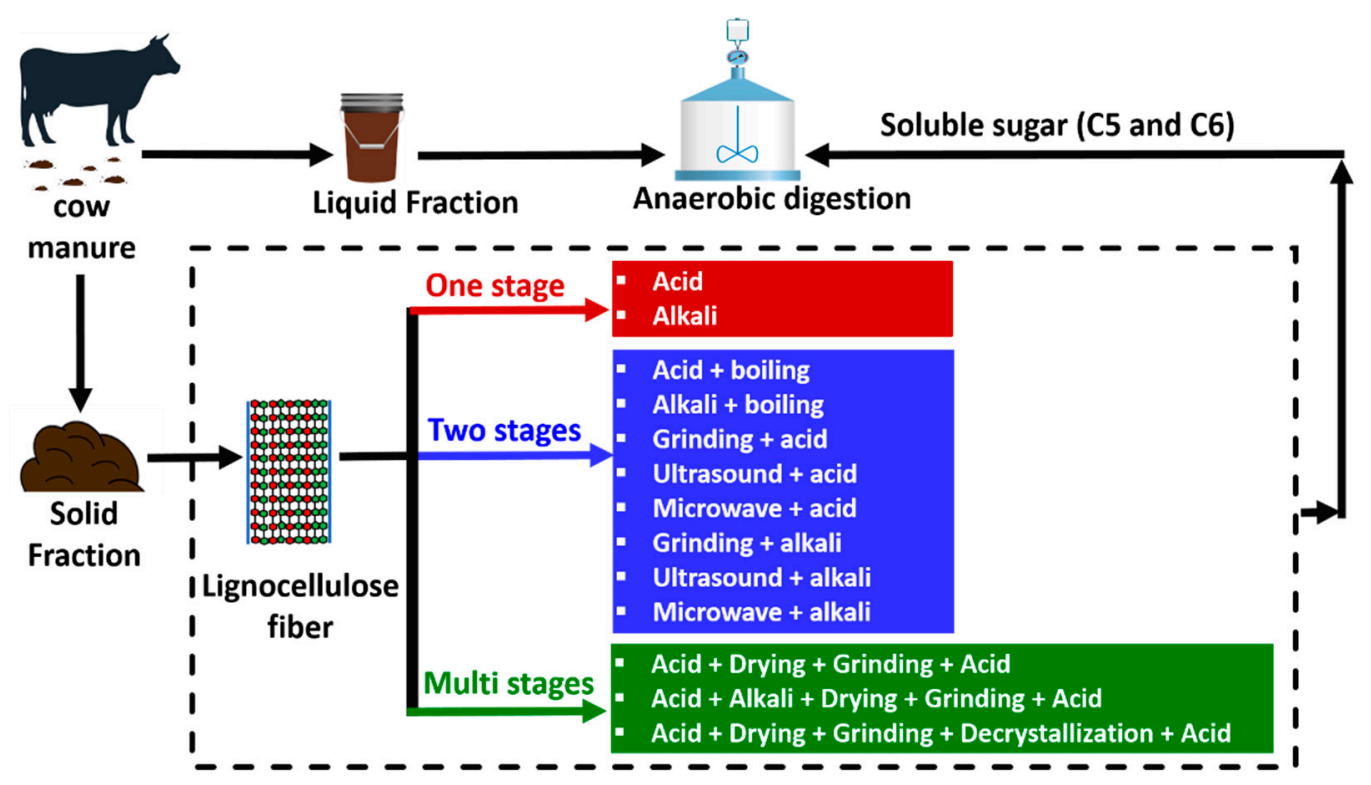

Figure 1. Chemical methods investigated for dairy manure hydrolysis.

\section{Lignocellulosic Biomass}

Lignocellulose consists of cellulose, hemicellulose, lignin, small amounts of minerals (ash), and other compounds. About $50-90 \%$ of the cellulose in lignocellulosic materials forms a crystalline structure [21]. Holocellulose (Hemicellulose and cellulose) contains fermentable monomers. Hemicellulose is broken down easier than cellulose [22].

Lignin in the lignocellulosic fraction of manure and the crystalline nature of cellulose make it inaccessible to the enzymes secreted by microorganisms during fermentation. Lignin and hemicellulose create a physical barrier protecting cellulose from the attack of hydrolytic enzymes $[23,24]$. Furthermore, the crystallinity of cellulose decreases its surface area exposed to enzymes [21]. Lignin resists the attack of microorganisms, enzymes, and chemicals by impeding them from penetrating the cell wall [25] and remains solid after most hydrolysis methods. It cannot be fermented and adversely impacts fermentation [26]; unfortunately, its removal is complex and expensive [22]. Lignin in plant residue must be broken or removed before the enzymatic hydrolysis of manure [25]. Cellulose crystallinity also impedes acid and enzymatic hydrolysis [27]. Because of the compact physical structure of lignocellulosic fibers, there is a relatively small surface area where microorganisms can attack the fiber and break it down [23]. Liao et al. [28] found that hemicellulose and lignin in dairy manure resisted enzymatic hydrolysis and that removal of one or both of them improved the enzymatic hydrolysis of the cellulose fibers. Completely converting manure's lignocellulosic fiber to methane requires three processes: 1- Delignifying the fiber to liberate cellulose and hemicellulose from lignin; 2- Depolymerizing cellulose and hemicellulose to produce free sugars (monomers); and 3- Fermenting hexose and pentose sugars to produce methane.

\section{Manure Composition}

Manure contains carbohydrates, proteins, lipids, and fats. It is rich in nutrients and micronutrients. Moreover, it contains hormones, antibiotics, and other medications that treat animals and a large consortium of microorganisms, including bacteria, archaea, protozoa, and fungi. Figure 2 gives the mass percentage of the major components of dairy manure. 


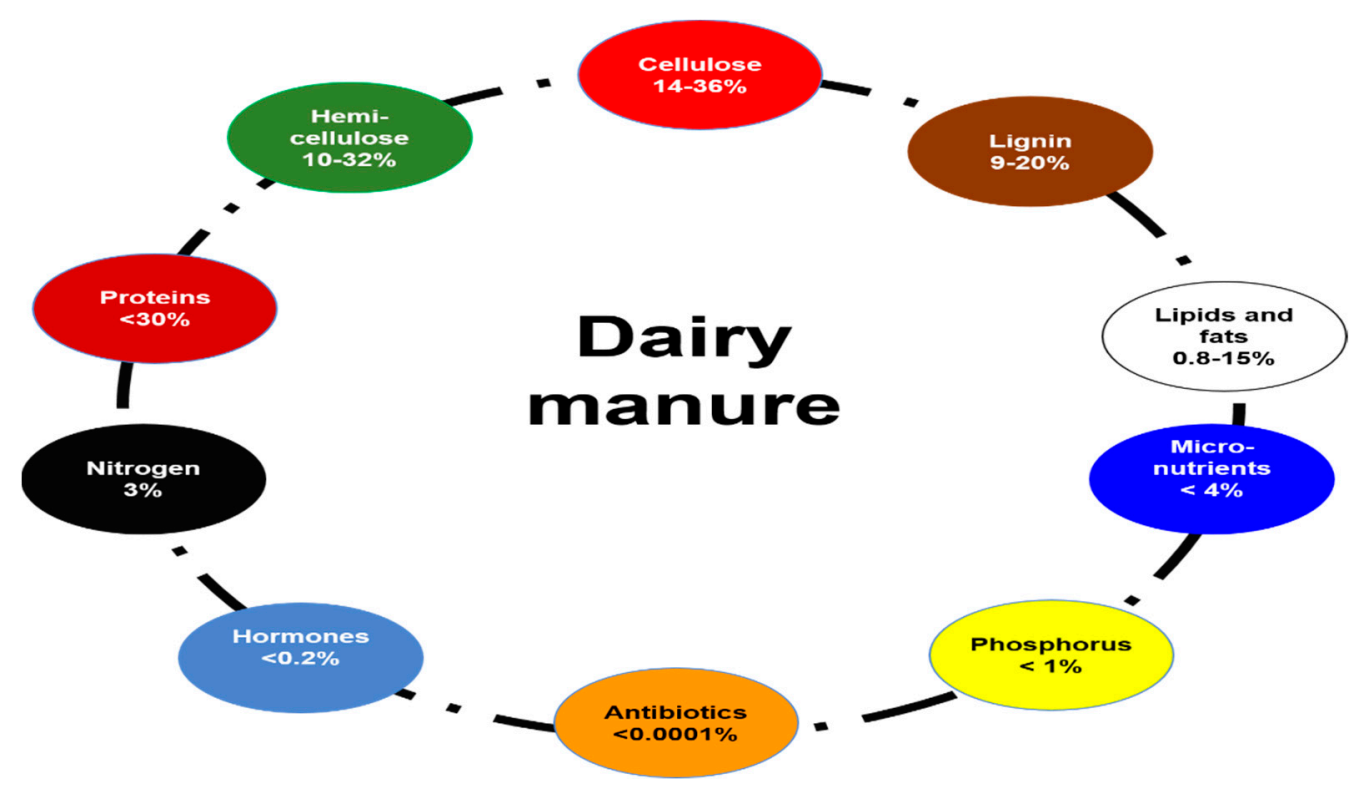

Figure 2. Composition of dairy manure (mass percent). The figures is based on data from [23,24,28-39].

\subsection{Biofibers}

Dairy manure comprises undigested animal feed lignocellulosic biomass and bedding material such as straw. Manure dry matter contains biofiber composed of three distinct components: readily hydrolyzable fraction (hemicellulose; $12-20 \%$ of DM [14-24 g kg dry manure]), slowly hydrolyzable fraction (cellulose; $16-26 \%$ of DM [25-31 $\mathrm{g} \mathrm{kg}^{-1}$ dry manure]) [28-31], and non-biodegradable lignin (7-14\% of DM). The biofiber composition of the cattle manure varies with the cattle diet. Table 2 illustrates the composition of cattle manure in different researches. Differences in the hydrolysis rate of hemicellulose (1.4 to $3 \mathrm{~d}^{-1}$ ) and cellulose $\left(0.09\right.$ to $\left.1.5 \mathrm{~d}^{-1}\right)[40,41]$ result in two distinct segments of temporal chemical oxygen demand (COD) solubilization [29]. These two segments require two different retention times for their anaerobic digestion. Therefore, pre-hydrolyzing cellulose would shorten the retention time and increase the rate of $\mathrm{CH}_{4}$ production.

Table 2. The content of cattle manure.

\begin{tabular}{|c|c|c|c|c|c|c|c|c|}
\hline \multicolumn{8}{|c|}{$\%$ of DM } & \multirow[b]{2}{*}{ References } \\
\hline $\begin{array}{l}\text { Total } \\
\text { Fiber }\end{array}$ & NDF & $\mathrm{ADF}$ & $\begin{array}{l}\text { Lignin } \\
\text { (ADL) }\end{array}$ & $\begin{array}{c}\text { Cellulose } \\
\text { (ADF-ADL) }\end{array}$ & $\begin{array}{l}\text { Hemicellulose } \\
\text { (NDF-ADF) }\end{array}$ & Lignin & Crude Protein & \\
\hline 52.6 & 52.6 & 40.4 & 13.0 & 27.4 & 12.2 & 13.0 & 18.1 & [32] \\
\hline 26.6 & & & & 19.5 & 14.4 & 16.2 & 16.3 & [31] \\
\hline 24.9 & & & & 21.0 & 19.6 & 12.2 & 29.7 & [31] \\
\hline 27.3 & & & & 16.2 & 20.9 & 19.0 & 18.0 & [31] \\
\hline \multirow[t]{6}{*}{82.5} & & 50.5 & 15.1 & 35.4 & 32 & & & [33] \\
\hline & & 2.8 & & 14.6 & 11.1 & 9.0 & 23.8 & [34] \\
\hline & & & & 22 & & 26 & 9 & [35] \\
\hline & 48.3 & 35.8 & 13.9 & 21.9 & 12.9 & & 16.5 & [36] \\
\hline & & & & 31.4 & 13.8 & 16.0 & 8.2 & [37] \\
\hline & 45.9 & & & 23.1 & 10.6 & 12.1 & 18.1 & [38] \\
\hline
\end{tabular}

Note: $\mathrm{ADF}=$ acid detergent fiber, $\mathrm{NDF}=$ neutral detergent fiber, and $\mathrm{ADL}=$ acid detergent lignin.

Manure biofiber is only partially degradable during AD [23,24,39]. Yue et al. [30] measured 357 and $322 \mathrm{~g}$ cellulose per $\mathrm{kg}$ of anaerobically digested fiber of dairy cow feces in a continuous stirring-tank reactor (CSTR) and a plug flow reactor (PFR), respectively. Therefore, fiber surviving the AD is relatively recalcitrant [42] and is mostly used as animal bedding and plant growing media [30]. However, its overall glucose conversion is similar 
to other energy crops. Increasing the biodegradability of manure fiber will enhance the economic feasibility of on-farm manure anaerobic digestion [23].

\subsection{Protein and Nitrogen Content}

Utilizing dairy manure is relatively more difficult than using other lignocellulosic biomass such as wood and straw because of its complex composition and substantial protein and nitrogen contents $(<20 \%$ and $3 \%$ of DM, respectively [32]). For example, the manure nitrogen content is higher than that in wheat straw (0.40-1\%) [43] and spruce wood $(0.20 \%)$ [44]. Therefore, the optimum conditions for manure hydrolysis will differ from that for other lignocellulosic materials because of the higher nitrogen content, differences in composition, and structure complexity [45].

Chen et al. [7] observed that the total nitrogen in manure filtrate is higher than that in solid particles. They concluded that sieving or simple decanting could separate protein from fibers. Such separation requires diluting the manure from $12 \%$ total solids (TS) to around $1 \%$ using water, increasing the reactor volume and the discharged effluent pollution. Nitrogen in cow manure is associated with indigestible forage proteins, proteins from rumen bacteria metabolism, and urine and ammonia (inorganic nitrogen) [32]. Ammonia and peptides of amino acids from hydrolyzed protein can react with mono-sugars during the hydrolysis, especially acid treatment, and decrease the yield of sugar [32] because high protein content favors side reactions such as browning reaction and dehydration [7]. More research is required to evaluate the effects of high nitrogen content on acid, alkali, and enzymatic hydrolysis of manure fiber to establish the optimum conditions and determine if another pretreatment is required. For example, there is a need to investigate the potential of ultrafiltration or carbon-bed adsorption to decrease the protein content of manure hydrolysate [45].

Liao et al. [46] reported that different treatments affected the nitrogen content of dry dairy manure fibers differently: untreated $(0.9 \%)$, dilute acid $(0.81 \%)$, sodium chlorite $(0.39 \%)$, combined dilute acid and sodium chlorite $(0.27 \%)$, and dilute alkaline hydrogen peroxide $(0.14 \%)$. Therefore, some treatments lowered the nitrogen content of dairy manure fibers to levels comparable to that of wheat straw (0.40-1.0\%) and spruce wood $(0.2 \%)$ fibers $[44,46]$. The manure inorganic minerals and nutrients could be concentrated in a fertilizer that is produced through AD. Production of such a fertilizer enables better management and control of the flux of nutrients into the environment.

\section{Hydrolysis}

Recently, an increasing number of reports are being published on the hydrolysis of manure lignocellulosic. Yang et al. [47] indicated that digestate resulting from the AD of animal manure still contains a high quantity of unconverted carbohydrate fibers. The cost of hemicellulose and cellulose hydrolysis forms about 33\% and 30\% of the overall cost of bioethanol production by enzymatic processes, respectively [48]. Therefore, hydrolyzing manure's recalcitrant lignocellulosic biofiber or its cellulosic fraction in dairy manure improves its $\mathrm{CH}_{4}$ yield and decreases the retention time. Accordingly, improved hemicellulose and cellulose hydrolysis technologies could reduce the cost of fermentative biofuel production [39,49].

Treatment of lignocellulosic residues before AD is necessary because the naturally occurring hydrolysis of non-pretreated materials in $\mathrm{AD}$ is slow and results in low $\mathrm{CH}_{4}$ yield $[19,41,50]$. Hydrolysis is a rate-limiting step in the AD of solid and particulate substrates $[29,41,50]$ such as dairy manure (total solids 12 to $24 \%$ ). Increasing the solids content decreases the hydrolysis rate [51]. Furthermore, the hydrolysis of cellulose is a rate-limiting step in converting cellulosic material to $\mathrm{CH}_{4}$ [52].

Hydrolysis treatment depolymerizes lignocellulose by disassociating lignin from the degradable part of fibers. It increases the accessibility of bacteria to the substrate [32]. In addition, they increase the specific surface area by recrystallizing cellulose and increasing its pore size [32,53]. Therefore, they make cellulose more accessible to cellulolytic enzymes [53]. 
Generally, pretreatments enhance subsequent enzymatic or acid hydrolysis to release sugar monomers $[26,54,55]$. Figure 3 represents the hydrolysis of cellulose and hemicellulose into simple sugars.
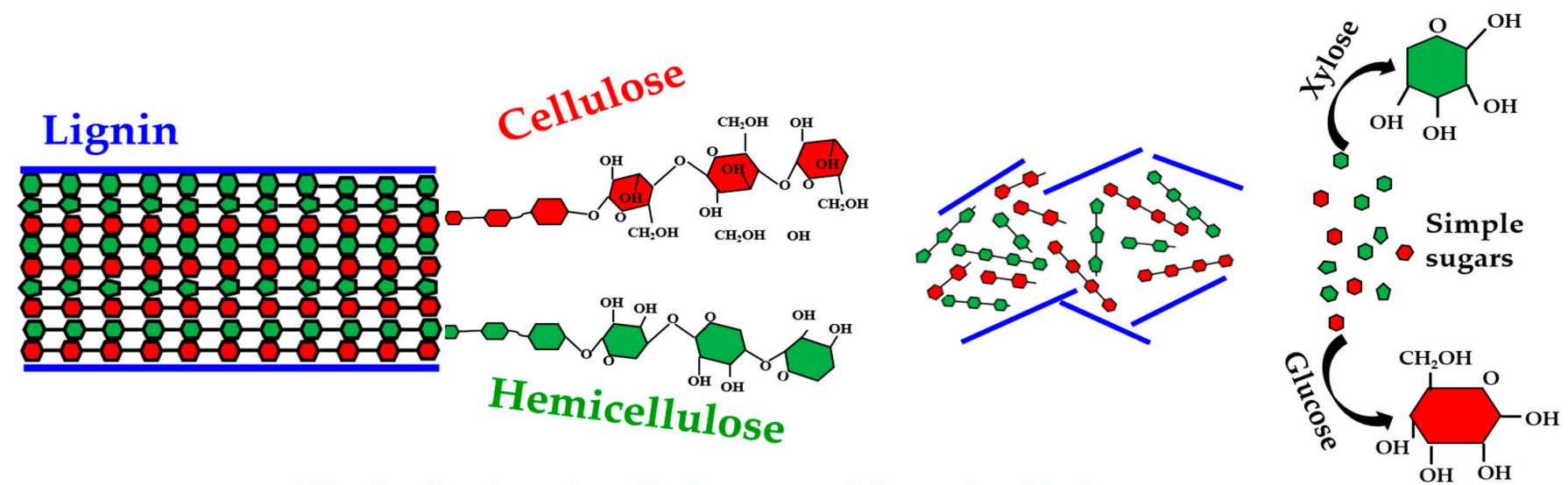

\section{Hydrolysis of cellulose and hemicellulose}

Figure 3. Schematic representation of the hydrolysis of cellulose and hemicellulose.

Pretreatment effectiveness depends on the characteristics of manure and the operating conditions that need to be optimized. Chen et al. [45] found that $56 \%$ of the total solids in dairy manure are fibers larger than $1.68 \mathrm{~mm}$ and only $24 \%$ of total solids are finer than $125 \mu \mathrm{m}$; notice that out of this $24 \%$ around $14 \%$ were dissolved solids. Therefore, particle size reducing pretreatments such as grinding and maceration may improve the hydrolysis of manure [24]. Decreasing manure fibers size to $0.35 \mathrm{~mm}$ by mechanical treatment increased the biogas potential by $20 \%$ [23]. In a relevant study, Hua et al. [56] reported a positive correlation between the hydrolysis rate and manure fineness. However, cost-benefit and practical applicability analyses are required to assess its suitability for on-farm conditions. Most of the carbon and nutrients in carbohydrates in manure are solid particles. Therefore, solid-liquid separation could enhance the full recovery of carbon and nutrient-rich organics from manure [7].

Neither treating manure fiber with $\mathrm{NaOH}, \mathrm{NH}_{4} \mathrm{OH}$, nor their combination increased $\mathrm{CH}_{4}$ yield. Similarly, neither mechanical and chemical treatment combined nor adding hemicellulolytic or cellulolytic enzymes increased the $\mathrm{CH}_{4}$ yield from the manure fiber [23]. Operationally, acid and alkali treatments require a continuous supply of acid or alkaline and energy input to heat the mixture for a specific time in specially designed reactors. Hence, thorough cost-effectiveness analysis and energy balance are required to establish the usefulness of these treatments.

\section{Pre- and Post-Treatments}

The pre- and post-treatments are intended to address the challenges encountered during manure hydrolysis. The challenges faced in dairy manure hydrolysis include [45].

1- Low surface area because large particles ( $>0.125 \mathrm{~mm}$ in size) form more than $75 \%$ of the dairy manure DM.

2- High protein content (around 20\% of the DM).

3- Low energy density or low fiber content (about $50 \%$ of the DM).

4- Low degradability of fiber.

Treatment of lignocellulosic should increase the sugar yield from manure sourced from different feeds and bedding materials. The pretreatment method could be used either by itself or in combination with a subsequent hydrolysis process. The successful method should meet the following requirements: it eliminates or minimizes sugar losses, minimizes the inhibitory by-products for subsequent hydrolysis and fermentation, does not require 
particle size reduction, is effective at low moisture content, is operationally compatible with anaerobic digestion, has minimum heat and energy requirements, and is cost-effective for the on-farm application [25]. The treatment method can be physical, physicochemical, chemical, and/or biological $[24,26]$. Physical ball milling and physicochemical steam explosion are examples of physical and physicochemical treatment [24,26]. Chemical methods involve digesting the fiber with acid, alkali, wet oxidation processes, sulfite, ammonia, and/or hydrogen peroxide. Biological methods mostly use fungi or purified enzymes [24,26]. Various combinations of these methods are also used depending on the nature of the biomass [57]. Physical or mechanical methods decrease the particle size of lignocellulosic fiber and decrystallize cellulose. Chemical methods dissolve lignin, hemicellulose, and/or cellulose crystalline structure using solvents. Acids, for example, speed up the solubilization and increase conversion yields [58-60].

Treatment of the lignocellulosic residues is necessary because the hydrolysis of nonpretreated materials is slow and results in low product yield. Some pretreatments increase the pore size and reduce the crystallinity of cellulose. Treatment also makes cellulose more accessible to cellulolytic enzymes, thus reducing enzyme requirements and cost [53]. Acid pretreatment targets hemicelluloses whereas alkali pretreatment removes lignin; thus, different raw materials require different treatments [61].

Liao et al. reported that dilute acid completely removed hemicellulose from dairy manure fiber and increased cellulose concentrations to $58 \%$ while sodium chlorite removed lignin and increased cellulose concentrations to $51 \%$, dilute alkaline peroxide removed hemicellulose and lignin, and increased cellulose concentrations to $65 \%$ [46]. They also reported that dilute acid and chlorite combined removed all hemicellulose and lignin and increased cellulose concentration to $83 \%$ [46].

\subsection{Acid Treatment}

Acid hydrolysis is commonly used to hydrolyze lignocellulose and produce sugar monomers by a combination of acid concentration and temperature. Either concentrated acid at low temperature $\left(10-30 \%\right.$ at $\left.<50{ }^{\circ} \mathrm{C}\right)$ or dilute acid at high temperature $(2-5 \%$ at $\left.120-230{ }^{\circ} \mathrm{C}\right)[24,36,62]$ for certain contact time $(1-4 \mathrm{~h})$ in a one-stage or a two-stage process [55]. Hua et al. [56] concluded that the ratio of manure to acid, reaction temperature, reaction time, initial acid concentration, and manure fineness significantly affected the hydrolysis rate. Generally, using dilute acid is less effective than concentrated acid hydrolysis. The acid concentration varied in literature; some reports referred to $3-10 \%$ acid as dilute and $12.5-75 \%$ as concentrated [55]. Hydrolysis of the hemicellulose which is attached to the surface of the crystal structure of cellulose in the manure fiber leaves cellulose in the solid residue. Concentrated acid is required to decrystallize the cellulose $[7,24]$.

Hydrolysis by dilute acid can be conducted in a one or two stages process. In a one-stage process, acid breaks the fiber structure to convert polysaccharides into mono sugars $[53,55]$. The first stage of a two-stage process uses dilute acid to solubilize and degrade hemicellulose into pentose sugar monomers. It also reduces cellulose crystallinity. The second stage uses concentrated acid $\left(\mathrm{H}_{2} \mathrm{SO}_{4}\right)$ to hydrolyze cellulosic fiber to mainly glucose [53,55]. Two-stage acid hydrolysis yielded more sugars from dairy manure than that produced in a one-stage process [32,55]. Yawson et al. [55] reported 15.5\% and 19.5\% sugar yields from one and two stages of microwave-assisted acid hydrolysis (Microwave $160{ }^{\circ} \mathrm{C}, 3 \% \mathrm{H}_{2} \mathrm{SO}_{4}$ ) for 20 and $5 \mathrm{~min}$, respectively (Table 3); however, the TS was $5.4 \%$ and $1.7 \%$, respectively, which seems to be dilute dairy manure compared to TS of $12-14 \%$ for fresh cow feces.

Yang et al. [24] reported that $4 \%$ sulfuric acid at $180{ }^{\circ} \mathrm{C}$ for $0.5 \mathrm{~h}$ removed $75.7 \%$ of the hemicellulose and $43.7 \%$ of lignin. Combining acid treatment $\left(4 \% \mathrm{H}_{2} \mathrm{SO}_{4}\right)$ with sodium sulfite ( $9 \%$ ) treatment resulted in $46.95 \%$ and $53.4 \%$ removal of hemicellulose and lignin, respectively [24]. 
Table 3. Performance of different procedures for acid hydrolysis (AH) of dairy manure.

\begin{tabular}{|c|c|c|c|c|c|c|c|c|}
\hline \multirow{2}{*}{$\begin{array}{l}\text { Procedure of } \\
\text { Hydrolysis }\end{array}$} & \multicolumn{4}{|c|}{ Stages of the Treatment Processes } & \multicolumn{2}{|c|}{$\begin{array}{l}\% \text { of the Total } \\
\text { Sugar Yield }\end{array}$} & \multirow{2}{*}{$\begin{array}{c}\text { Lignin } \\
\text { Removal } \\
(\%)\end{array}$} & \multirow[t]{2}{*}{ References } \\
\hline & & & & & C6 & C5 & & \\
\hline One-stage with decrystallization & \multicolumn{2}{|c|}{$\begin{array}{l}\text { Decrystallization } \\
\text { (70\% acid, } 0.25 \mathrm{~h})\end{array}$} & $(100$ & $\begin{array}{l}\mathrm{AH}^{1} \\
20 \% \text { acid, } 1 \mathrm{~h})\end{array}$ & 31 & 70 & & {$[32]$} \\
\hline One stage & \multicolumn{4}{|c|}{$\mathrm{AH}\left(170{ }^{\circ} \mathrm{C}, 20 \%\right.$ acid, $\left.10 \mathrm{~min}\right)$} & 9 & 22 & & [32] \\
\hline Two-stages with grinding & $\mathrm{AH}\left(120^{\circ} \mathrm{C}, 3 \%\right.$ acid, $\left.1 \mathrm{~h}\right)$ & $\begin{array}{l}\text { Drying and } \\
\text { Grinding }\end{array}$ & \multicolumn{2}{|c|}{$\mathrm{AH}\left(170{ }^{\circ} \mathrm{C}, 20 \%\right.$ acid, $\left.10 \mathrm{~min}\right)$} & 28 & 95 & & [32] \\
\hline $\begin{array}{l}\text { Two-stages with alkaline } \\
\text { extraction }\end{array}$ & $\mathrm{AH}\left(120^{\circ} \mathrm{C}, 3 \%\right.$ acid, $\left.1 \mathrm{~h}\right)$ & $\begin{array}{l}\text { Alkaline extraction } \\
\left(2 \% \mathrm{NaOH}, 25^{\circ} \mathrm{C}\right)\end{array}$ & $\begin{array}{l}\text { Drying and } \\
\text { Grinding }\end{array}$ & $\mathrm{AH}\left(170^{\circ} \mathrm{C}, 3 \%\right.$ acid, $\left.10 \mathrm{~min}\right)$ & 19 & 95 & & [32] \\
\hline Two-stages with decrystallization & $\mathrm{AH}\left(120^{\circ} \mathrm{C}, 3 \%\right.$ acid, $\left.1 \mathrm{~h}\right)$ & $\begin{array}{l}\text { Drying and } \\
\text { Grinding }\end{array}$ & $\begin{array}{l}\text { Decrystallization } \\
(70 \% \text { acid, } 0.25 \mathrm{~h})\end{array}$ & $\mathrm{AH}\left(100^{\circ} \mathrm{C}, 20 \%\right.$ acid, $\left.1 \mathrm{~h}\right)$ & 89 & 95 & & [32] \\
\hline One-stage & \multicolumn{4}{|c|}{$\mathrm{AH}\left(180^{\circ} \mathrm{C}, 4 \%\right.$ acid, $\left.0.5 \mathrm{~h}\right)$} & NR & 75.5 & 43.7 & [24] \\
\hline One-stage & \multicolumn{4}{|c|}{$\mathrm{AH}$ and Sodium sulfite $\left(180^{\circ} \mathrm{C}, 4 \%\right.$ acid, $9 \%$ sulfite, $\left.0.5 \mathrm{~h}\right)$} & & 46.9 & 53.4 & [24] \\
\hline Two-stages with microwave & \multicolumn{2}{|c|}{$\mathrm{AH}\left(\mathrm{MW}^{2} 160^{\circ} \mathrm{C}, 3 \%\right.$ acid, $\left.20 \mathrm{~min}, \mathrm{TS} 5.4 \%\right)$} & \multicolumn{2}{|c|}{$\mathrm{AH}\left(\mathrm{MW} 160{ }^{\circ} \mathrm{C}, 3 \%\right.$ acid, $5 \mathrm{~min}, \mathrm{TS} 1.7 \%$ ) } & 19.5 & & & [55] \\
\hline One-stage & \multicolumn{4}{|c|}{$1 \% \mathrm{H}_{2} \mathrm{SO}_{4}, 135^{\circ} \mathrm{C}$, and $5 \%$ substrate for $2 \mathrm{~h}$} & 58 & & & [46] \\
\hline One-stage & \multicolumn{4}{|c|}{$1 \% \mathrm{H}_{2} \mathrm{SO}_{4}, 135^{\circ} \mathrm{C}$, and $10 \%$ dairy manure for $2 \mathrm{~h}$} & 21 & & & [63] \\
\hline One-stage & \multicolumn{4}{|c|}{$1 \% \mathrm{H}_{2} \mathrm{SO}_{4}$ at $140{ }^{\circ} \mathrm{C}$ and $2.8 \mathrm{~h}$ reaction time, } & 34 & & & [38] \\
\hline
\end{tabular}


The overall glucose conversion (65\%) from the enzymatic hydrolysis of alkali pretreated dairy cow feces' fibers was higher than that from the enzymatic hydrolysis of dilute acid $\left(\mathrm{H}_{2} \mathrm{SO}_{4}\right)$ pretreated fibers (22-30\%) [30]. However, Kaparaju and Angelidaki [39] found that neither $\mathrm{NaOH}$ nor $\mathrm{CaO}\left(40 \mathrm{~g} \mathrm{~kg}^{-1} \mathrm{VS}\right)$ increased the biodegradability and $\mathrm{CH}_{4}$ yield of thermophilically $\left(55^{\circ} \mathrm{C}\right)$ digested cow manure fibers compared to that of untreated fibres (Table 4). Yang et al. [24] reported the ranking of the increase in the methane yield (\%) upon chemical hydrolysis: alkaline (50\%) > alkaline and polyethylene glycol (34.2\%) $>$ acid and sulfite $(26.3)>$ alkaline and thiourea $(21.1 \%)>$ acid $(6.8 \%)$. Excessive alkaline may oxidize the cellulose to oxycellulose (glucose converted to glucuronic acid residues by oxidation) which is very difficult to be degraded by acid or other chemicals. Chen et al. [7] reported that two-stage acid hydrolysis without alkaline treatment released the highest amount of mono-sugars from dairy manure.

Chen et al. [32,45] investigated different procedures for the acid hydrolysis of dairy manure (Table 3). The reported optimal combinations of processes in two-stage hydrolysis of dairy manure fibers are (Table 3): acid hydrolysis $\left(120^{\circ} \mathrm{C}, 3 \%\right.$ acid, $\left.1 \mathrm{~h}\right)$, drying and grinding, decrystallization (70\% acid, $0.25 \mathrm{~h}$ ), and acid hydrolysis $\left(100{ }^{\circ} \mathrm{C}, 20 \%\right.$ acid, $\left.1 \mathrm{~h}\right)$ which yielded $89 \%$ and $95 \%$ of the total sugars in hemicellulose and cellulose, respectively.

One-stage acid hydrolysis of dairy manure at optimal conditions of $\left(120{ }^{\circ} \mathrm{C}, 3 \%\right.$ $\mathrm{H}_{2} \mathrm{SO}_{4}, 1 \mathrm{~h}$ ) yielded a maximum of $14 \mathrm{~g}$ mono-sugars per $100 \mathrm{~g}$ dry manure (i.e., $14 \%$ yield); hemicellulose was completely broken down into arabinose, galactose, and xylose with yields of 2.8, 1.7, $7.2 \mathrm{~g}$ of sugar per $100 \mathrm{~g}$ of dry manure (a total pentose yield of 12\%), respectively [45]. However, the glucose yield was low (1.67\%) compared with the cellulose content ( $27 \%$ of the dry manure). Although glucose yield increases with temperature, too high temperature enhances dehydration reactions and degrades the produced monosugars quickly. Therefore, multi-step acid hydrolysis is preferred to obtain and retain these mono-sugars $[7,28]$.

Decrystallization (with 75\% acid, 3:5 sample: acid ratio, for $30 \mathrm{~min}$ ) followed by dilute acid hydrolysis $\left(12.5 \%\right.$ acid, $10 \%$ sample, $130{ }^{\circ} \mathrm{C}$ for $\left.10 \mathrm{~min}\right)$ gave the best results of 26 g glucose $\mathrm{L}^{-1}$ (conversion rate of $84 \%$ ) and $11 \mathrm{~g} x y l o s e ~^{-1}$ (conversion rate of $80 \%$ ) [7]. Liao et al. indicated that the glucose yield ( $84 \%$ ) of acid hydrolysis of dairy manure was almost similar to that from the hydrolysis of sweetchip (85\%) though the acid concentration used in the second step (12.5\%) was lower compared to that used in the sweetchip wood hydrolysis (68\%) [64].

Acid pretreatment increases lignin content to about $50 \%$ of the treated anaerobically digested cow manure fiber [30]; high lignin content hinders the enzyme action on the fiber or binds to active enzymes before they reach cellulose [28,30]. The high alkalinity of cow manure anaerobically digested fiber adversely affects dilute acid pretreatment. Consequently, the high alkalinity lowers glucose yield and overall glucose conversion efficiency of the enzymatic hydrolysis [30]. Acid pretreatment is preferred when fungal enzymes are chosen to hydrolyze lignocellulosic biomass because many fungal cellulolytic enzymes favor low pH (usually 4-5) [61]. Generally, multi-step acid hydrolysis is preferred to obtain and retain these mono-sugars $[7,28,45]$.

\subsection{Alkali Treatment}

Alkali-based pretreatments use dilute or strong bases such as ammonia $\left(\mathrm{NH}_{3}\right)$, lime $\left(\mathrm{Ca}(\mathrm{OH})_{2}\right)$, and sodium hydroxide $(\mathrm{NaOH})$ to solubilize the lignocellulose (Table 4$)$. Among the bases $\mathrm{NaOH}, \mathrm{KOH}, \mathrm{NH}_{4} \mathrm{OH}, \mathrm{Ca}(\mathrm{OH})_{2}$, the latter is the cheapest; calcium can also be recovered in the form of insoluble calcium carbonate by neutralizing calcium with $\mathrm{CO}_{2}$, while $\mathrm{NaOH}$ is the most commonly used because of its better solubilization efficiency $[19,65]$. $\mathrm{NaOH}$ could interrupt the hydrogen bond in cellulose and hemicellulose, and the breakage of ester linkages between lignin and xylan; thus, it deprotonates the phenolic groups [66]. 
Table 4. Performance of different procedures for alkaline and other treatments for hydrolysis of dairy manure.

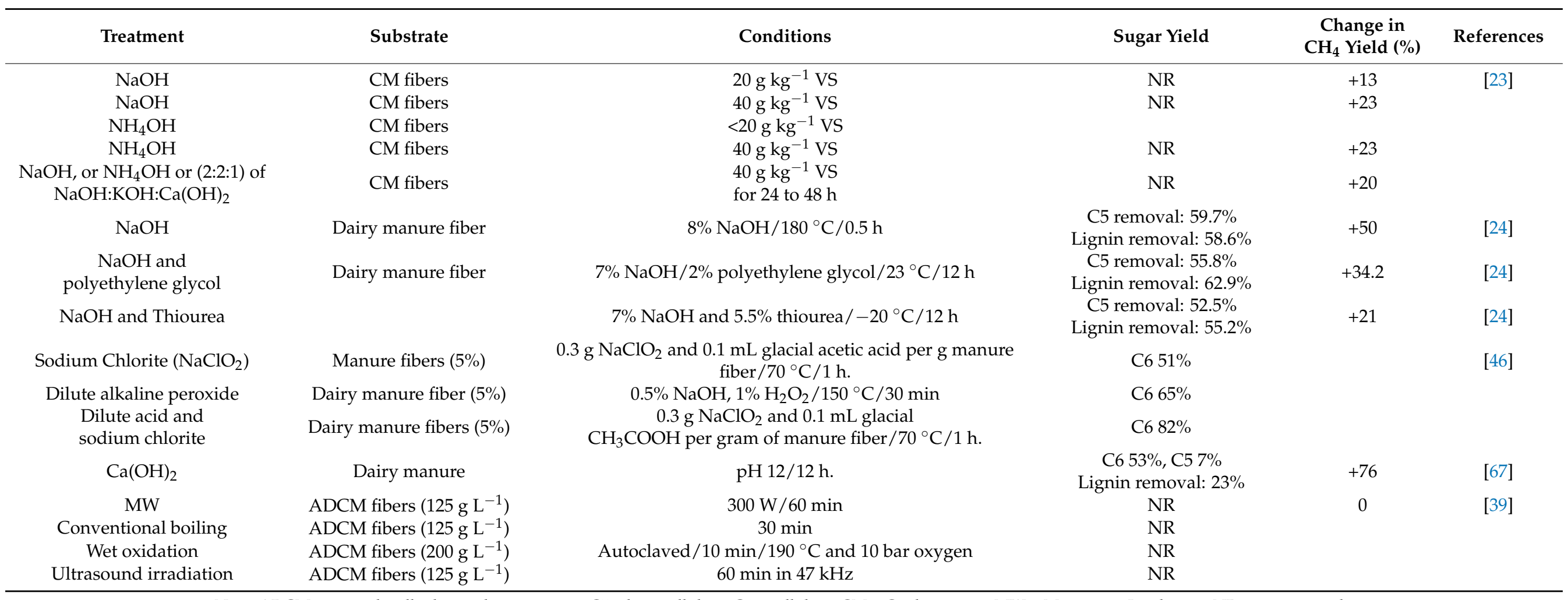

Note: $\mathrm{ADCM}$ = anaerobically digested cow manure; $\mathrm{C} 5$ = hemicellulose; $\mathrm{C} 6$ = cellulose; $\mathrm{CM}=$ Cattle manure; $\mathrm{MW}=$ Microwave Irradiation; $\mathrm{NR}=$ not reported. 
Effect of the base only $\left(\mathrm{NaOH}, \mathrm{KOH}, \mathrm{Ca}(\mathrm{OH})_{2}, \mathrm{NH}_{4} \mathrm{OH}\right.$ or combination of them without the temperature) increased the methane yield from cattle manure by 13-23\% [23]. In comparison, using temperature $\left(180{ }^{\circ} \mathrm{C}\right)$ with $\mathrm{NaOH}$ increased the methane yield by $50 \%$ [24] (Table 4). Adding 5.5\% thiourea or $2 \%$ polyethylene glycol to $\mathrm{NaOH}$ increases the methane yield by $21 \%$ and $34 \%$, respectively [24]. Interestingly $100 \%$ of $\mathrm{Ca}(\mathrm{OH})_{2}$ increased the methane yield by $76 \%$ [67].

Alkaline pretreatment swells and depolymerizes the fiber structure, thus increasing the internal surface area. It removes lignin and hemicellulose partially and increases cellulose content in the anaerobically digested fiber. Alkali treatment uses dilute $\mathrm{NaOH}$ or $\mathrm{KOH}(2 \%$ to $4 \%)$ at temperatures $\left(25-120^{\circ} \mathrm{C}\right)$ for 1 to $48 \mathrm{~h}[23,32,58]$ to delignify cellulose in lignocellulosic biomass and increases its porosity $[30,68]$. This increases its internal surface area [58]. Delignification is an important step in enhancing cellulosic fraction conversion in the anaerobically digested fibers into glucose [30].

\subsection{Other Relevant Treatments}

Microwave irradiation, conventional boiling, wet oxidation (hydrogen peroxide $\left.\left(\mathrm{H}_{2} \mathrm{O}_{2}\right)\right)$, ultrasound irradiation, sodium sulfite, and advanced oxidation processes (AOP) or their combination have been investigated to enhance dairy manure hydrolysis (Table 4). None of these methods increased the $\mathrm{CH}_{4}$ yield though all of them except the ultrasound irradiation increased the soluble chemical oxygen demand (SCOD) of the anaerobically digested manure fibers. Kaparaju and Angelidaki [39] speculated that wet oxidation using $\mathrm{H}_{2} \mathrm{O}_{2}$ might have released possible inhibitors from the lignin which inhibited $\mathrm{CH}_{4}$ production from the treated fibers. Hydrogen peroxide has been demonstrated to destroy solids, release the reducing sugar, and solubilize nutrients (nitrogen, phosphorus, and minerals); however, high dosages of $\mathrm{H}_{2} \mathrm{O}_{2}$ could oxidize the mono-sugars [55]. Yawson et al. [55] treated dairy manure using a combination of microwave irradiations and $\mathrm{H}_{2} \mathrm{O}_{2}$ with dilute $\mathrm{H}_{2} \mathrm{SO}_{4}$ in a two-stage process to convert fibers into reducing sugar. They obtained a maximum reducing sugar yield of $15.5 \%$ from dilute acid treatment at $160{ }^{\circ} \mathrm{C}$ for $20 \mathrm{~min}$ but without $\mathrm{H}_{2} \mathrm{O}_{2}$.

Thermal pretreatment of fibers from cattle manure using an autoclave $\left(130-160{ }^{\circ} \mathrm{C}\right)$ for one hour increased the reactivity of cellulose towards commercial cellulase 4-6 times compared to $\mathrm{NaOH}$ treatment and 10-12 times compared with untreated fibers; however, the temperature of $198^{\circ} \mathrm{C}$ for one hour burned the wood and resulted in low reactivity [69].

In conclusion, it appears that a pre- or post-treatment is required to hydrolyze the cow manure fiber and fully extract its sugar content. Figure 4 presents two proposed configurations of (A) pre-treatment, and (B) post-treatment. The choice between a pre- or post-treatment depends on the logistics, the desired ultimate usage of the digestate, downstream treatment options, energy analysis, and economic analysis. The post-treatment configuration (Figure 4A,B) might be more advantageous because the digestate is concentrated with fibers, increased cellulose content, and low nitrogen and protein content compared to undigested raw manure. The choice between a pre- or post-treatment would depend on the manure quantity and its economic feasibility. A practical aspect that needs some attention is the $\mathrm{pH}$ of the hydrolyzed effluent. Both acid and alkaline hydrolysis processes produce an effluent with extreme $\mathrm{pH}$, low $\mathrm{pH}$ in acid treatment, and high $\mathrm{pH}$ in alkaline treatment. Therefore, a $\mathrm{pH}$-equilibrating step might be required based on the mass balance of the hydrolyzed sugar stream and the raw or fresh dairy manure. The latter is characterized by its high alkalinity content, and might buffer the low $\mathrm{pH}$ of the hydrolyzed sugar stream from the acid treatment. Generally, washing the hydrolysate with tap water several times to bring its $\mathrm{pH}$ to a moderate value (about 5) was used both after acid and alkaline treatment [7,24]. For example, Chen et al. [7] washed the acid-treated manure slurry with hot tap water to increase its $\mathrm{pH}$ to 5.0. For a process design, they suggested a calcium carbonate neutralization process to adjust the $\mathrm{pH}$ of the acid hydrolysis effluent. 
(A)

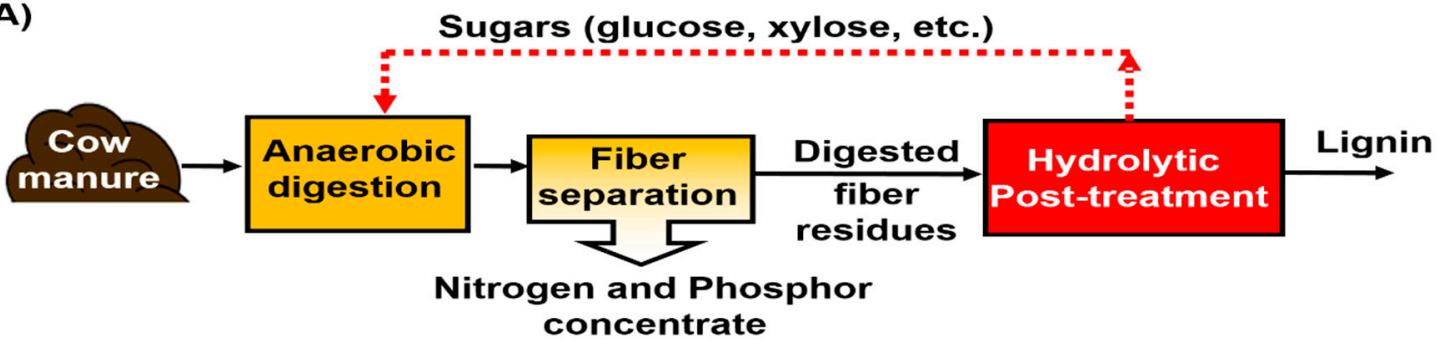

(B)

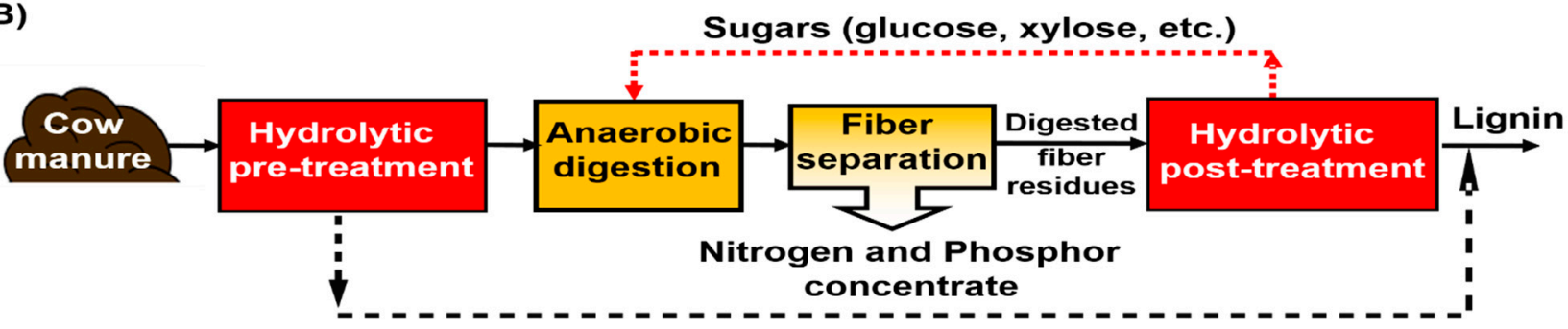

Figure 4. The proposed hydrolysis treatment configuration for manure energy recovery: (A) post-treatment and (B) preand post-treatment.

A potential issue might arise regarding the compatibility of the acid and alkaline hydrolysis process with the commonly used manure composting process. The solid residue from the hydrolysis process is mainly lignin. Previous studies demonstrated that acid hydrolysis, for example, destroyed the crystal structure of the lignocellulose manure fiber and converted it to an amorphous powder composed of lignin with very small quantities of sugar [36]. This structural destruction of the manure fibers and the extensive extraction of the sugars render the residue of the acid and alkaline unsuitable for composting because lignin is non-biodegradable. Moreover, the amorphous powder structure does not provide any bulking effects.

\section{Areas for More Research and Development}

More research is required to evaluate the effects of high nitrogen content on acid, alkali, and enzymatic hydrolysis of manure fiber to establish the optimum conditions and determine if another pretreatment is required. For example, the potential of ultrafiltration or carbon-bed adsorption to decrease the protein content of manure hydrolysate needs to be investigated [45]. Effects of the chemical hydrolysis of manure fiber on the microbial community and its metabolic functions requires insight through molecular biology methods. Economic analysis and energy balance should be monolithic components of the research on the anaerobic digestion of manure to evaluate the benefit gained from incorporating manure fiber hydrolysis in on-farm biogas projects.

\section{Conclusions}

Generally, dilute acid is less effective than concentrated acid which decrystallizes the cellulose, while excessive alkaline may produce difficult-to-degrade oxycellulose. Multistep acid hydrolysis (without alkaline) is preferred because it yielded $84 \%$ and $80 \%$ manureto-glucose and -xylose conversion, respectively. The studies must pay attention to acid pretreatment because it increases lignin concentration in the treated manure and hinders subsequent enzymatic processes.

The ratio of manure to the chemical agent and its initial concentration, reaction temperature and duration, and manure fineness need optimization because they affect the hydrolysis rate. Optimizing these factors or combining processes should seek a balance between removing hemicellulose and/or lignin and increasing cellulose concentrations while not hindering any subsequent process.

The reviewed processes are not yet economical or integratable with the on-farm anaerobic digestion. Economic analysis and energy balance should be monolithic components of 
the research. More research is required to assess the effects of nitrogen content on these processes, optimize it, and determine if another pretreatment is necessary. Effects of the chemical hydrolysis of manure fiber on the microbial community and its metabolic function require insight through molecular biology methods.

Author Contributions: Conceptualization, N.M.C.S.; literature review, N.M.C.S., F.R. and J.E.R.E.; analysis of the literature data, N.M.C.S., F.R.; writing-original draft preparation, N.M.C.S. and F.R.; writing-review and editing, N.M.C.S., F.R. and J.E.R.E.; visualization, F.R.; funding acquisition, N.M.C.S. All authors have read and agreed to the published version of the manuscript.

Funding: This research was funded by Natural Sciences and Engineering Research Council of Canada (NSERC) through the Discovery Grant program for anaerobic digestion of nitrogen-rich feedstock, and the Government of Newfoundland and Labrador through the Canadian Agriculture Partnership administrated by the Department of Fisheries, Forestry, and Agriculture.

Institutional Review Board Statement: Not applicable.

Informed Consent Statement: Not applicable.

Data Availability Statement: Not applicable.

Conflicts of Interest: The authors declare no conflict of interest.

\section{References}

1. Hofmann, N.; Beaulieu, M.S. A Geographical Profile of Manure Production in Canada; Statistics Canada, Agriculture Division: Ottawa, ON, Canada, 2006. Available online: https:/ / publications.gc.ca/Collection/Statcan/16F0025X/16f0025xib-h.pdf (accessed on 21 September 2021).

2. Wen, Z.; Liao, W.; Chen, S. Hydrolysis of animal manure lignocellulosics for reducing sugar production. Bioresour. Technol. 2004, 91, 31-39. [CrossRef]

3. Klass, D.L. Biomass for Renewable Energy, Fuels, and Chemicals; Elselvier Press: San Diego, CA, USA, 1998; ISBN 13: $978-0124109506$.

4. Ravindranath, N.H.; Somashekar, H.I.; Nagaraja, M.S.; Sudha, P.; Sangeetha, G.; Bhattacharya, S.C.; Abdul Salam, P. Assessment of sustainable non-plantation biomass resources potential for energy in India. Biomass Bioenerg. 2005, 29, 178-190. [CrossRef]

5. Wendt, C.; Ellis, C.; Guillen, D.P.; Feris, K.; Coats, E.R.; McDonald, A. Reduction of GHG emissions through the conversion of dairy waste to value-added materials and products. In Energy Technology; Li, L., Ed.; Springer: Cham, Switerland, 2016. Available online: https:/ /link.springer.com/chapter/10.1007/978-3-319-48182-1_13\#citeas (accessed on 21 September 2021). [CrossRef]

6. Liebrand, C.B.; Ling, K.C. Cooperative Approaches for Implementation of Dairy Manure Digesters; Rural Development; USDA: Washington, DC, USA, 2009. Available online: http:/ / purl.access.gpo.gov/GPO/LPS117368 (accessed on 21 September 2021). [CrossRef]

7. Chen, S.; Liao, W.; Liu, C.; Wen, Z.; Kincaid, R.L.; Harrison, J.H.; Elliott, D.C.; Brown, M.D.; Solana, A.E.; Stevens, D.J. Value-Added Chemicals From Animal Manure. Northwest Bioproducts Research Institute, 2003. Available online: http: //www.adktroutguide.com/files/Elliott_PNNL_value_from_manure.pdf (accessed on 21 September 2021).

8. Environment, E.C.-D.; Collection and Analysis of Data for the Control of Emissions from the Spreading of Manure. Final Report. 2014. Available online: https:/ / ec.europa.eu/environment/air/pdf/Final\%20Report.pdf (accessed on 21 September 2021).

9. Steffen, R.; Szolar, O.; Braun, R. Feedstocks for Anaerobic Digestion; Institute for Agrobiotechnology-Tulln: Vienna, Austria, 1998.

10. Jia, W.; Qin, W.; Zhang, Q.; Wang, X.; Ma, Y.; Chen, Q. Evaluation of crop residues and manure production and their geographical distribution in China. J. Clean. Prod. 2018, 188, 954-965. [CrossRef]

11. Guo Guo, L. Potential of Biogas Production from Livestock Manure in China: GHG Emission Abatement from "ManureBiogas-Digestate" System. Master's Thesis, Chalmers University of Technology, Göteborg, Sweden, 2010. Available online: https:/ / publications.lib.chalmers.se/records/fulltext/155056.pdf (accessed on 21 September 2021).

12. Rao, P.V.; Baral, S.S.; Dey, R.; Mutnuri, S. Biogas generation potential by anaerobic digestion for sustainable energy development in India. Renew. Sustain. Energy Rev. 2010, 14, 2086-2094. [CrossRef]

13. Noorollahi, Y.; Kheirrouz, M.; Asl, H.F.; Youse, H.; Hajinezhad, A. Biogas production potential from livestock manure in Iran. Renew. Sustain. Energy Rev. 2015, 50, 748-754. [CrossRef]

14. El-Nahrawy, M.A. Country Pasture/Forage Resource Profiles: Egypt; FAO: Rome, Italy, 2011. Available online: https:/ /docplayer.net/ 47325686-Country-pasture-forage-resource-profiles-egypt-by-dr-mohamed-a-el-nahrawy.html (accessed on 21 September 2021).

15. Batzias, F.A.; Sidiras, D.K.; Spyrou, E.K. Evaluating livestock manures for biogas production: A GIS based method. Renew. Energy 2005, 30, 1161-1176. [CrossRef]

16. Oliveira, A.C.L.d.; Milagres, R.S.; Orlando Junior, W.d.A.; Renato, N.d.S. Evaluation of Brazilian potential for generating electricity through animal manure and sewage. Biomass Bioenerg. 2020, 139, 105654. [CrossRef]

17. Albihn, A.; Vinnerås, B. Biosecurity and arable use of manure and biowaste-Treatment alternatives. Livest. Sci. 2007, 112, 232-239. [CrossRef] 
18. Wilkie, A.C. Anaerobic digestion of dairy manure: Design and process considerations. Nat. Resour. Agric. Eng. Serv. 2005, 176, 301-312.

19. Muhammad Nasir, I.; Mohd Ghazi, T.I. Pretreatment of lignocellulosic biomass from animal manure as a means of enhancing biogas production. Eng. Life Sci. 2015, 15, 733-742. [CrossRef]

20. Nasir, I.M.; Mohd Ghazi, T.I.; Omar, R. Anaerobic digestion technology in livestock manure treatment for biogas production: A review. Eng. Life Sci. 2012, 12, 258-269. [CrossRef]

21. Brigham, J.S.; Adney, W.S.; Himmel, M.E. Handbook on Bioethanol: Production and Utilization; Wyman, C., Ed.; CRC Press: Boca Raton, FL, USA, 1996; pp. 119-141.

22. Jacobsen, S.E.; Wyman, C.E. Cellulose and hemicellulose hydrolysis models for application to current and novel pretreatment processes. Appl. Biochem. Biotechnol. Part A Enzym. Eng. Biotechnol. 2000, 81-96. [CrossRef]

23. Angelidaki, I.; Ahring, B.K. Methods for increasing the biogas potential from the recalcitrant organic matter contained in manure. Water Sci. Technol. 2000, 41, 189-194. [CrossRef] [PubMed]

24. Yang, Q.; Wang, H.; Larson, R.; Runge, T. Comparative study of chemical pretreatments of dairy manure for enhanced biomethane production. BioResources 2017, 12, 7363-7375. Available online: https://ojs.cnr.ncsu.edu/index.php/BioRes/article/view/ BioRes_12_4_7363_Yang_Chemical_Pretreatments_Dairy_Manure/5522 (accessed on 21 September 2021).

25. Sun, Y.; Cheng, J. Hydrolysis of lignocellulosic materials for ethanol production: A review. Bioresour. Technol. 2002, 83, 1-11. [CrossRef]

26. Taherzadeh, M.J.; Karimi, K. Pretreatment of lignocellulosic wastes to improve ethanol and biogas production: A review. Int. J. Mol. Sci. 2008, 9, 1621-1651. [CrossRef]

27. Kuhad, R.C.; Singh, A.; Eriksson, K.E. Microorganisms and enzymes involved in the degradation of plant fiber cell walls. Adv. Biochem. Eng. Biotechnol. 1997, 57, 45-125. [CrossRef]

28. Liao, W.; Wen, Z.; Hurley, S.; Liu, Y.; Liu, C.; Chen, S. Effects of hemicellulose and lignin on enzymatic hydrolysis of cellulose from dairy manure. Appl. Biochem. Biotechnol. Part A Enzym. Eng. Biotechnol. 2005, 124, 1017-1030. [CrossRef]

29. Myint, M.; Nirmalakhandan, N. Evaluation of first-order, second-order, and surface-limiting reactions in anaerobic hydrolysis of cattle manure. Environ. Eng. Sci. 2006, 23, 970-980. [CrossRef]

30. Yue, Z.; Teater, C.; MacLellan, J.; Liu, Y.; Liao, W. Development of a new bioethanol feedstock-Anaerobically digested fiber from confined dairy operations using different digestion configurations. Biomass Bioenerg. 2011, 35, 1946-1953. [CrossRef]

31. Amon, T.; Amon, B.; Kryvoruchko, V.; Zollitsch, W.; Mayer, K.; Gruber, L. Biogas production from maize and dairy cattle manure-Influence of biomass composition on the methane yield. Agric. Ecosyst. Environ. 2007, 118, 173-182. [CrossRef]

32. Chen, S.; Wen, Z.; Liao, W.; Liu, C.; Kincaid, R.L.; Harrison, J.H.; Elliott, D.C.; Brown, M.D.; Stevens, D.J. Studies into using manure in a biorefinery concept. Appl. Biochem. Biotechnol. Part A Enzym. Eng. Biotechnol. 2005, 124, 999-1015. [CrossRef]

33. Jaster, E.H.; Newman, H.R.; McCoy, G.C.; Staples, C.R.; Berger, L.L.; Fahey, G.C. Dairy waste fiber as a roughage source for dairy heifers. J. Dairy Sci. 1982, 65, 1234-1239. [CrossRef]

34. Rorick, M.B.; Spahr, S.L.; Bryant, M.P. Methane production from cattle waste in laboratory reactors at $40^{\circ}$ and $60{ }^{\circ} \mathrm{C}$ after solid-liquid separation. J. Dairy Sci. 1980, 63, 1953-1956. [CrossRef]

35. Park, J.; Cho, K.H.; Ligaray, M.; Choi, M.J. Organic matter composition of manure and its potential impact on plant growth. Sustainability 2019, 11, 2346. [CrossRef]

36. Liao, W.; Liu, Y.; Liu, C.; Wen, Z.; Chen, S. Acid hydrolysis of fibers from dairy manure. Bioresour. Technol. 2006, 97, 1687-1695. [CrossRef] [PubMed]

37. Liao, W.; Liu, Y.; Frear, C.; Chen, S. Co-production of fumaric acid and chitin from a nitrogen-rich lignocellulosic material-Dairy manure-Using a pelletized filamentous fungus Rhizopus oryzae ATCC 20344. Bioresour. Technol. 2008, 99, 5859-5866. [CrossRef] [PubMed]

38. Liao, W.; Liu, Y.; Wen, Z.; Frear, C.; Chen, S. Studying the effects of reaction conditions on components of dairy manure and cellulose accumulation using dilute acid treatment. Bioresour. Technol. 2007, 98, 1992-1999. [CrossRef]

39. Kaparaju, P.L.-N.; Angelidaki, I. Effect of post-treatments on biodegradability and methane recovery from fibres separated from thermophilically digested cow manure. In Proceedings of the 11th IWA World Congress on Anaerobic Digestion, Brisbane, Australia, 23-27 September 2007.

40. Myint, M.; Nirmalakhandan, N.; Speece, R.E. Anaerobic fermentation of cattle manure: Modeling of hydrolysis and acidogenesis. Water Res. 2007, 41, 323-332. [CrossRef]

41. Vavilin, V.A.; Rytov, S.V.; Lokshina, L.Y. A description of hydrolysis kinetics in anaerobic degradation of particulate organic matter. Bioresour. Technol. 1996, 56, 229-237. [CrossRef]

42. Tambone, F.; Genevini, P.; D'Imporzano, G.; Adani, F. Assessing amendment properties of digestate by studying the organic matter composition and the degree of biological stability during the anaerobic digestion of the organic fraction of MSW. Bioresour. Technol. 2009, 100, 3140-3142. [CrossRef]

43. Reinertsen, S.A.; Elliott, L.F.; Cochran, V.L.; Campbell, G.S. Role of available carbon and nitrogen in determining the rate of wheat straw decomposition. Soil Biol. Biochem. 1984, 16, 459-464. [CrossRef]

44. Winter, F.; Wartha, C.; Hofbauer, $\mathrm{H}$. $\mathrm{NO}$ and $\mathrm{N}_{2} \mathrm{O}$ formation during the combustion of wood, straw, malt waste and peat. Bioresour. Technol. 1999, 70, 39-49. [CrossRef] 
45. Chen, S.; Liao, W.; Liu, C.; Kincaid, R.L.; Harrison, J.H. Use of animal manure as feedstock for bio-products. In Proceedings of the 9th International Symposium on Animal, Agricultural and Food Processing Wastes, Raleight, NC, USA, 12-15 October 2003; Burns, R.T., Ed.; ASAE: Washington, DC, USA, 2003; pp. 50-57. [CrossRef]

46. Liao, W.; Liu, Y.; Wen, Z.; Frear, C.; Chen, S. Kinetic modeling of enzymatic hydrolysis of cellulose in differently pretreated fibers from dairy manure. Biotechnol. Bioeng. 2008, 101, 441-451. [CrossRef]

47. Yang, Q.; Zhou, S.; Runge, T. Dairy manure as a potential feedstock for cost-effective cellulosic bioethanol. BioResources 2016, 11, 1240-1254. [CrossRef]

48. Hinman, N.D.; Schell, D.J.; Riley, J.; Bergeron, P.W.; Walter, P.J. Preliminary estimate of the cost of ethanol production for ssf technology. Appl. Biochem. Biotechnol. 1992, 34-35, 639-649. [CrossRef]

49. Kaparaju, P.; Rintala, J. Anaerobic co-digestion of potato tuber and its industrial by-products with pig manure. Resour. Conserv. Recycl. 2005, 43, 175-188. [CrossRef]

50. Vavilin, V.A.; Shchelkanov, M.Y.; Rytov, S.V. Effect of mass transfer on concentration wave propagation during anaerobic digestion of solid waste. Water Res. 2002, 36, 2405-2409. [CrossRef]

51. Motte, J.C.; Trably, E.; Escudié, R.; Hamelin, J.; Steyer, J.P.; Bernet, N.; Delgenes, J.P.; Dumas, C. Total solids content: A key parameter of metabolic pathways in dry anaerobic digestion. Biotechnol. Biofuels 2013, 6, 164. [CrossRef] [PubMed]

52. Noike, T.; Endo, G.; Chang, J.-E.; Yaguchi, J.-I.; Matsumoto, J.-I. Characteristics of carbohydrate degradation and the rate-limiting step in anaerobic digestion. Biotechnol. Bioeng. 1985, 27, 1482-1489. [CrossRef]

53. Mosier, N.; Wyman, C.; Dale, B.; Elander, R.; Lee, Y.Y.; Holtzapple, M.; Ladisch, M. Features of promising technologies for pretreatment of lignocellulosic biomass. Bioresour. Technol. 2005, 96, 673-686. [CrossRef] [PubMed]

54. Hendriks, A.T.W.M.; Zeeman, G. Pretreatments to enhance the digestibility of lignocellulosic biomass. Biores. Technol. 2009, 100, 10-18. [CrossRef] [PubMed]

55. Yawson, S.K.; Liao, P.H.; Lo, K.V. Two-stage dilute acid hydrolysis of dairy manure for nutrient release, solids reduction and reducing sugar production. Nat. Res. 2011, 2, 224-233. [CrossRef]

56. Hua, Q.-X.; Zhang, L.; Tang, J.-W.; Liu, Y.; Chen, J. Hydrolysis properties of livestock manure in sulphuric acid solutions. Guangzhou Chem. Ind. 2013, 2, 7.

57. McMillan, J.D. Pretreatment of lignocellulosic biomass. In Enzymatic Conversion of Biomass for Fuels Production; Himmel, M.E., Baker, J.O., Overend, R.P., Eds.; American Chemical Society: Washington, DC, USA, 1994; pp. 292-324.

58. Champagne, P.; Li, C. Bio-product recovery from lignocellulosic materials derived from poultry manure. Bull. Sci. Technol. Soc. 2008, 28, 219-226. [CrossRef]

59. Lloyd, T.A.; Wyman, C.E. Combined sugar yields for dilute sulfuric acid pretreatment of corn stover followed by enzymatic hydrolysis of the remaining solids. Bioresour. Technol. 2005, 96, 1967-1977. [CrossRef] [PubMed]

60. Prasad, S.; Singh, A.; Joshi, H.C. Ethanol as an alternative fuel from agricultural, industrial and urban residues. Res. Conserv. Recycl. 2007, 50, 1-39. [CrossRef]

61. Hahn-Hägerdal, B.; Galbe, M.; Gorwa-Grauslund, M.F.; Lidén, G.; Zacchi, G. Bio-ethanol—The fuel of tomorrow from the residues of today. Trends Biotechnol. 2006, 24, 549-556. [CrossRef]

62. Kumar, P.; Barrett, D.M.; Delwiche, M.J.; Stroeve, P. Methods for pretreatment of lignocellulosic biomass for efficient hydrolysis and biofuel production. Ind. Eng. Chem. Res. 2009, 48, 3713-3729. [CrossRef]

63. Liao, W.; Liu, Y.; Liu, C.; Chen, S. Optimizing dilute acid hydrolysis of hemicellulose in a nitrogen-rich cellulosic material—Dairy manure. Bioresour. Technol. 2004, 94, 33-41. [CrossRef]

64. Bayat-Makooi, F.; Singh, T.M.; Goldstein, I.S. Some factors influencing the rate of cellulose hydrolysis by concentrated acid. Biotechnol. Bioeng. Symp. 1985, 15, 27-37.

65. Aftab, M.; Iqbal, I.; Riaz, F.; Karadag, A.; Tabatabaei, M. Different pretreatment methods of lignocellulosic biomass for use in biofuel productionnt pretreatment methods of lignocellulosic biomass for use in biofuel production. In Biomass for BioenergyRecent Trends and Future Challenges; IntechOpen: London, UK, 2019.

66. Janker-Obermeier, I.; Sieber, V.; Faulstich, M.; Schieder, D. Solubilization of hemicellulose and lignin from wheat straw through microwave-assisted alkali treatment. Ind. Crops Prod. 2012, 39, 198-203. [CrossRef]

67. Niasar, H.S.; Karimi, K.; Zilouei, H.; Salehian, P.; Jeihanipour, A. Effects of lime pretreatment on biogas production from dry dairy cattle manure. Minerva Biotechnol. 2011, 23, 77-82.

68. Silverstein, R.A.; Chen, Y.; Sharma-Shivappa, R.R.; Boyette, M.D.; Osborne, J. A comparison of chemical pretreatment methods for improving saccharification of cotton stalks. Bioresour. Technol. 2007, 98, 3000-3011. [CrossRef]

69. Nesse, N.; Wallick, J.; Harper, J.M. Pretreatment of cellulosic wastes to increase enzyme reactivity. Biotechnol. Bioeng. 1977, 19, 323-336. [CrossRef] 